\title{
CRADLE TO CRADLE IN RESIDENTIAL BUILDING: THE FEASIBILITY TO IMPLEMENT THE CRADLE TO CRADLE CONCEPT IN RESIDENTIAL BUILDING
}

Olga Brommet*, Jouke Post**

*) Delft University of Technology, CIE 5910 Functional Design in Civil Engineering.

**) Eindhoven University of Technology, Faculty of Architecture

e-mail: studio@xxarchitecten.nl

\begin{abstract}
Sustainability and Cradle to Cradle are well known concepts for creating buildings. The aim of the article here want to discuss the implementation of Cradle to Cradle in residential building. The method used were literature study and case study. A building is $100 \%$ cradle to cradle when every part of the building meets the standard of the C2C principles, includes material health and reutilization, use of renewable energy, water stewardship and social fairness. The result of the study shows that the case study match $89 \%$ of cradle to cradle score, which was a good result.
\end{abstract}

Keywords: cradle to cradle, residential building, construction, renewable energy, design process, material certification.

\section{INTRODUCTION}

Sustainability is a well-known concept in the building industry since quite some time. All kinds of various applications and visions are available to make a new or existing building more sustainable. Next to sustainability, another concept is available: Cradle to Cradle. The roots of this concept are in product development, but can be extended to bigger constructions like houses. A lot of research already exists; even some existing buildings contain cradle to cradle aspects. But a complete cradle to cradle building is new. In the Netherlands the first cradle to cradle house is built in 2012. The question raises: What is the result of this building? Is it feasible to build Cradle to Cradle? For this paper we will investigate the following research question:

'Is it feasible to design and build a complete cradle to cradle residential building?' 
For investigation of this research question, the following sub questions are needed to be answered: What is Cradle to Cradle? And what is Cradle to Cradle in the construction industry? What are the effects for the design processes? Which findings of cradle to cradle designing and building are known? What are the conditions for building Cradle to Cradle? Answering these questions helps to determine the feasibility to build cradle to cradle in residential building and which conditions are required. This research will give an introduction in building cradle to cradle and the idea behind it.

\section{THEORY / RESEARCH METHODS}

\section{Cradle to Cradle}

Concept

The Cradle to Cradle philosophy started in 2002 with the book 'Cradle to Cradle: Remaking the Way We Make Things' written by William McDonough and Micheal Braungart (MBDC, 2014). Cradle to Cradle is elaborated from the idea that natural resources are exhaustible. Until now we live in a consumptive society, without caring about what will happen with our waste. We take out resources, we make something of it and we throw away the rests. Also known as the cradle to grave design paradigm, visualized in Figure 1.

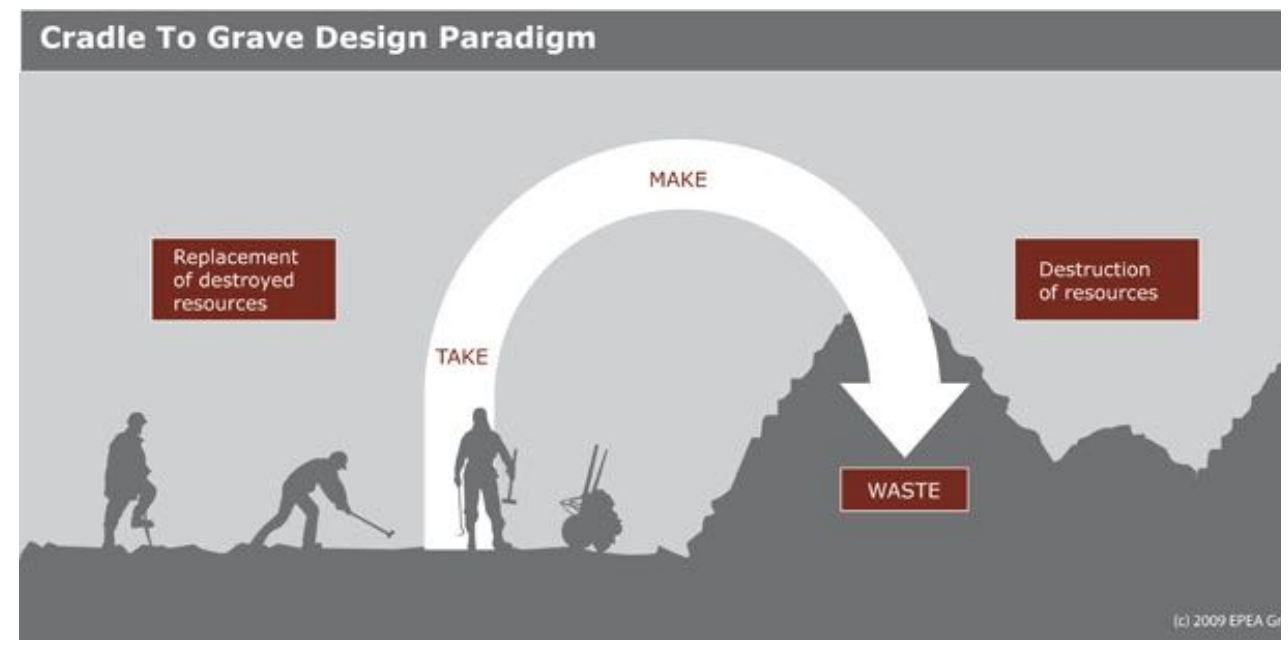

Figure 1. Cradle to Grave Design Paradigm EPEA (2014b) Source: EPEA, 2014

Sustainable design is about reuse, reduce and recycle for doing less badly. Sustainability does not consider the total life cycle of a product, such as the production process does. The Cradle to Cradle concept means doing ' $100 \%$ good', effective use of materials and consideration of the total life cycle of a produc. 
Important in the $\mathrm{C} 2 \mathrm{C}$ philosophy is that materials do not decrease in quality during their life cycle and could even improve in quality (MBDC, 2011). The concept is based on 3 basic ideas:

1. Waste = Food; so keep all materials in the biological or technical cycle.

2. Use only renewable energy, such as from the solar, wind and water.

3. Respect diversity; make sure that the material/product adds something to the nature environment.

The Cradle to Cradle concept is about re-using biological and technical resources, as shown Figure 2. The used materials are designed in such a way that it is possible to keep the material in the biological or technical process after its lifecycle and to maintain those cycles. It is rather 'borrowing' the material for usage, instead of keeping it. In every stadium of the life cycle of a material, be it production or re-use, it is necessary to use renewable energy, threat water as precious resource and respect to have respect for people and natural systems. Therefor improvement of industrial processes and the materials is needed (EPEA, 2014b) (MBDC, 2014).

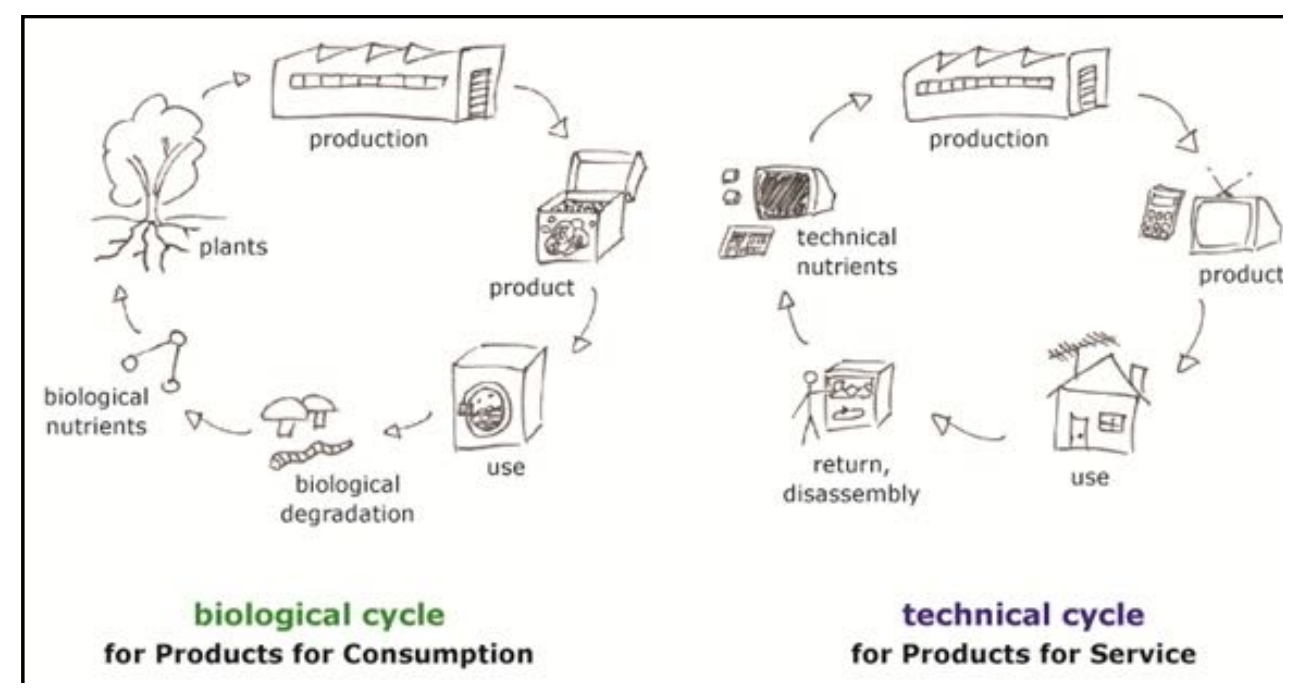

Figure 2. Biological and Technical cycle Source: Timmermans, 2014

\section{Applicability in residential building}

Implementing the $\mathrm{C} 2 \mathrm{C}$ concept in residential buildings requires new standards. These standards are prescriptions for making buildings $\mathrm{C} 2 \mathrm{C}$ and are also the criteria to test the building if it is fully $\mathrm{C} 2 \mathrm{C}$. There are several ideas about what these standards are; however, some ideas or concepts do have similarities which will be described below. The basic idea of Cradle to Cradle of 'doing good' and 'borrowing' the material is still applicable in every cradle to cradle concept for residential buildings. A Cradle to Cradle building has to give a positive effect on the environment, which is called eco-effective (Beemster, 2012). 
Andy van der Dobbelsteen (2008) proposes a new strategy for making buildings cradle to cradle. His idea starts with the current conditions of the building (site). Than look at the environment and use the characteristics of it in the design so consider the climate, landscape and so on and use it on building level. Let the building interact with the environment. The second step is about re-use, use all the biological and technical cycles optimal, like energy, water and materials. The last step is about the remaining aspects of the building. Make sure that every product is clean and toxic-free, so that waste can become food in the next cycle.

In a $\mathrm{C} 2 \mathrm{C}$ home design competition with their students, Anna Marshall-Baker and Lisa Marshall-Baker and Tucker (2012) had to determine what Cradle to Cradle is about. They stated that $\mathrm{C} 2 \mathrm{C}$ considers solar energy, diversity of living organisms, natural models in which waste equals food, social equity, environmental quality, economic health and industrial processes and materials.

Both approaches described above consider three different levels: macro-, meso- and micro level. The Macro level is the environment of the location, the meso level is about the relation between the environment and the location and the micro level looks at the substance of the building itself.

Certification of building materials is the same as how other products can get a Cradle to Cradle certification. There are five levels: basic, bronze, silver, gold and platinum for $100 \% \mathrm{C} 2 \mathrm{C}$ material. The certifications of the materials are used by measurement tools which evaluate and test the building to the cradle to cradle criteria. It can be stated that a building is $100 \%$ cradle to cradle when every part of the building, at every level meets the standard of the $\mathrm{C} 2 \mathrm{C}$ principles regarding material health, material reutilization, use of renewable energy, the water stewardship and the social fairness (Dalen, 2013).

There are several measurement tools available which evaluate and test the $\mathrm{C} 2 \mathrm{C}$ level of the building according to the principles. These tools can help during the design phase to improve the $\mathrm{C} 2 \mathrm{C}$ level of the design. One of the tools was developed by the C2Clabxx which makes a distinction between the macro-, meso-, and micro level (Beemster, 2012). The tool tests the building on the aspects environment, design, installation and materialisation by giving a score between the 32 and +32 . Evaluation of these scores indicates how much a building is $\mathrm{C} 2 \mathrm{C}$ according to the various aspects in percentages (Velden, 2012). See Figure 7 in the case study for an example.

Another method was produced by LEED. LEED was a certification method which was more focussed on sustainability, but the latest version LEED V4 was developed by McDonough and Braungart and use the $\mathrm{C} 2 \mathrm{C}$ principles for the certification procedure (News, 2013). A building which consist at least $20 \mathrm{C} 2 \mathrm{C}$ certified products can qualify for this certification.

The $\mathrm{C} 2 \mathrm{C}$ tools look at the vision of doing better, the eco effectiveness, instead of the sustainable certifications what is about doing less bad. Well known sustainable certifications are breglobal and Breeam, but it is possible that they will develop the certification method to $\mathrm{C} 2 \mathrm{C}$ as well (Dalen, 2013). 


\section{Design Process}

It is essential to include the cradle to cradle concept early in the design process to make a cradle to cradle house. If an existing design does not meet the $\mathrm{C} 2 \mathrm{C}$ requirements it will cost a lot of money and energy to improve the design according to the $\mathrm{C} 2 \mathrm{C}$ principles, but even then it will worth doing so. From the moment that the design is sufficiently $\mathrm{C} 2 \mathrm{C}$, improvements can be made for the right cradle to cradle implementation for the specific location (Alston, 2008). To maximize the quality of these improvements collaboration between all stakeholders is very important, already early in the design phase. Furthermore room is needed for pilot projects, as building Cradle to cradle is new and for innovations and improvements pilots are needed (Berg et al., 2012).

The design process for a cradle to cradle building do have the same steps as other design processes, but the vision differs. Designing is an iterative process, which should result in the most optimal design. Designing a $\mathrm{C} 2 \mathrm{C}$ house starts with inspiration and use of the cradle to cradle concept is a lens to the design object. The second step is about identification of the location, environment and people to gain information about it and to set goals for the design. Thereafter the exploration phase starts: drawing various design concepts which include these goals. Refinement of this phase is needed to organize all the ideas. The last step is the evaluation, with as result a well-formed design, according to the $\mathrm{C} 2 \mathrm{C}$ principles along with a concept guide (Marshall-Baker \& Tucker, 2012).

Three stages can be identified from the above: it starts conceptual with ideas, then it became more energetically and it ends with thinking on component level (Klooster, 2008).

\section{Materialization}

The materialization of the building is what cradle to cradle really is about and where the biggest improvements can be made for now and in the future, because under current conditions it is almost impossible to build 100\% C2C. The Cradle to Cradle paradigm states that the materials are in continuous loops; waste equals food. This means that there are specific requirements for the materialization; they need to be of high quality and dissembling of the product is required (Velden, 2012). These specific requirements are classified in five aspects, which can be tested to certify how much the material is $\mathrm{C} 2 \mathrm{C}$.

The first aspect is about the status of the material. Because $\mathrm{C} 2 \mathrm{C}$ is about the cycles, it is necessary that it is possible to demolish the material so that it can be reused again. Therefor knowledge about the way of production of the material is a required. If toxics are used in the material it will harm the nature and people.

The second aspect is about the re-use ability of the material in the technical or biological cycle. The possibilities to the extent of re-usability can be different for every component of the material. Furthermore, the materials need to be found nearby, or fit into the environment well. The third and fourth aspects are about the production process. During production energy will be needed, but when nonrenewable energy is used the material will be less $\mathrm{C} 2 \mathrm{C}$. Another aspect of the 
production process is the waste produced, mainly the waste water. It is important that the water still is clean after production. The last aspect is about the behaviour of the company who produces the material. The company needs to be good for people and planet, what is often defined in their business ethics. (MBDC, 2011)

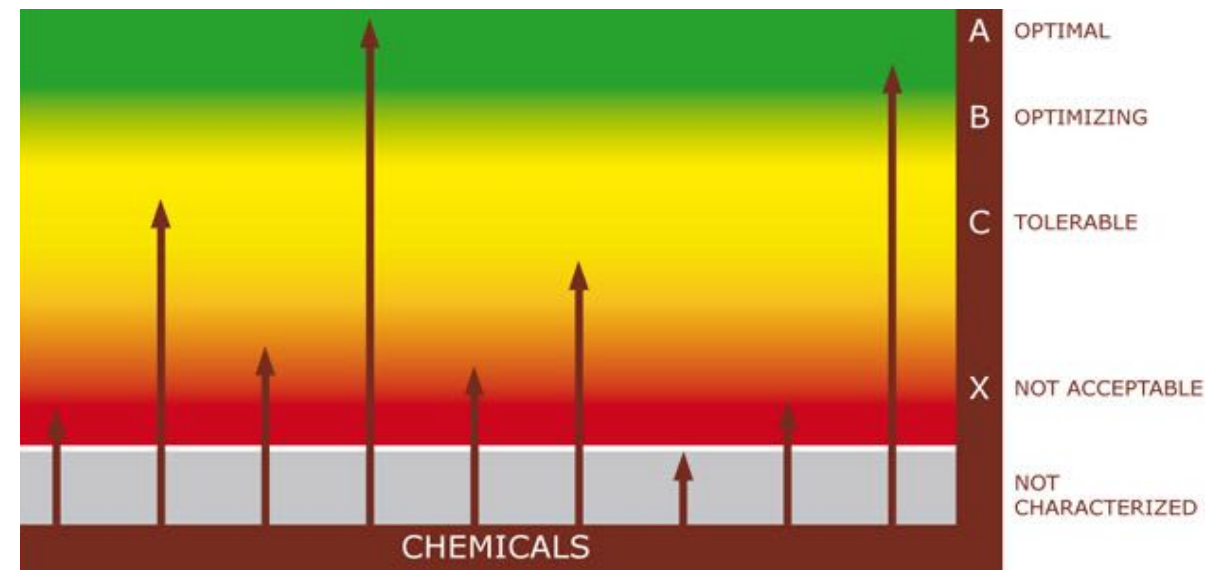

Figure 3. ABC-X certification: degree of acceptance materials Source: EPEA, 2014a

Evaluation of the material against the $\mathrm{C} 2 \mathrm{C}$ aspects can be done by an $\mathrm{ABC}-\mathrm{X}$ investigation. Herewith the $\mathrm{C} 2 \mathrm{C}$ quality of the various components can be determined. This evaluation exists of four steps: 1 . the identification of all the used materials and chemicals. 2. a base of the risk profile is made by information form EPEA of all the materials ecologic and toxicologist characteristics. 3. exists of an evaluation of the available data and 4. a recommendation (EPEA, 2014a). General recommended is an ABC-X certification of a material, see Figure 3 which shows the acceptance in different degrees of $\mathrm{C} 2 \mathrm{C}$ principles regarding some fictional materials is visualised.

It is mentioned above that it is almost impossible under current conditions to build completely $\mathrm{C} 2 \mathrm{C}$, because not every building material with a good certificate is available (Beemster, 2012). Therefor the contractors have to adjust their production process with respect to the $\mathrm{C} 2 \mathrm{C}$ principles and not everyone is in favour of doing so. The use of toxic glue or other materials is still very common, even the $\mathrm{C} 2 \mathrm{C}$ design tool does not take this aspect into account. Talking and negotiating with the contractors is required to create their support to avoid the use of toxic materials (Hannema, 2013).

\section{Cradle to Cradle example concepts}

In the last decade a lot of research was done about the possibility of the $\mathrm{C} 2 \mathrm{C}$ concept in buildings and that still is going on. The office and expo building called 'breathing space' was part of the floriade 2012 in Venlo and built with the C2C concept in mind. It was a public event, so it was possible to create public' awareness of the $\mathrm{C} 2 \mathrm{C}$ concept in buildings. During this event another $\mathrm{C} 2 \mathrm{C}$ design was designed and 
awarded; the municipal office of Venlo. Other C2C designs are the park 20/20 in Hoofddorp and the redevelopment of the Philips fabrics. There are also 'virtual' $\mathrm{C} 2 \mathrm{C}$ buildings designed and reviewed on the feasibility. One was a prototype house in Switzerland and another house was designed for a master thesis, with the focus on the materialization. In the United States students and architects competed in a C2C Home Design competition, the best designs of this contest is published in a book by Marshall-Baker and Tucker (2012). The most important finding is that the willingness of all the parties involved in the design and construction process is very important. Involving every party in an early stage of the design will have the advantage that in the process of the project will keep speed. These parties can be the government, for the required permits or the investor because $\mathrm{C} 2 \mathrm{C}$ can have higher investment costs. Most important is involvement of the contractors in an early phase, for realising a $\mathrm{C} 2 \mathrm{C}$ building the materials need to be produced according certain requirements and not every desired material will be available.

\section{Research Method}

To answer the research question, a literature study and case study will be done. The literature study exists of research into the idea of the cradle to cradle concept and the way it can be used in buildings, especially residential buildings. The literature study will provide the information what cradle to cradle building is which will help to look critically at the case study. The case study is the second part of the paper, wherein the house 'Recht op Wind' will be discussed which according to the published articles about the building is the first cradle to cradle house in the Netherlands. This will result in a discussion about the research question and a final conclusion.

\section{RESULTS AND DISCUSSION}

\section{Case Study}

Now it is clear what the $\mathrm{C} 2 \mathrm{C}$ concept means for buildings, it is possible to look at a case study of a cradle to cradle residential building. For this case study a closer look will be taken at the construction of the house 'Recht op Wind', the first cradle to cradle house built in the Netherlands. The design is made by XX architects, the owner Jouke Post is one of them. They used the construction of this residential building as an ultimate test in practice, one big step further to a completely $\mathrm{C} 2 \mathrm{C}$ house.

\section{C2C Concept \& Design}

Next to the $\mathrm{C} 2 \mathrm{C}$ philosophy, the user has certain requirements on the house: the application of the $\mathrm{C} 2 \mathrm{C}$ principles should not affect the comfort of the house. Furthermore the maintenance of the house had to be low. The design approach was creating a pleasant house, with a nice view on the environment and well oriented to the sun, but also optimally embedded in the environment. These requirements along 
with the three $\mathrm{C} 2 \mathrm{C}$ principles, an extension of the key rules was necessary which resulted in the following design rules (Post, 2011):

1. Do not use toxic in the materials

2. Use renewable energy; the $\mathrm{C} 2 \mathrm{C}$ philosophy states that they are unlimited (Beemster, 2012). Use of minimum number of installations.

3. Use diversity as enrichment

4. The surrounding flora and fauna is an important design element

5. The wellbeing and comfort is a condition for the result

It is already mentioned that design according to the $\mathrm{C} 2 \mathrm{C}$ principles requires another design approach. The design rules can be contradictory; resolve designing is an efficient way to include all the requirements in the design process. At first it should be decided how to include the qualities of the environment in the design and how to use the orientation in the landscape, taking into account the sun and wind direction. After these criteria are fully met in the design, the number of installations can be determined (Hannema, 2013).

For a Cradle to Cradle design, the used materials need to be Cradle to Cradle. The materialization of the house is included in the design process, so testing the design against the $\mathrm{C} 2 \mathrm{C}$ criteria will give insight in the required improvements and possibilities for even a better $\mathrm{C} 2 \mathrm{C}$ design. During the design of 'Recht op Wind' the design tool developed by C2Clabxx is used for testing all the materials and systems.

\section{Process construction}

The process in advance of the construction has different aspects which could result in a change of the design. The aspects with a $\mathrm{C} 2 \mathrm{C}$ context will be discussed briefly: permissions, available materials and hiring contractors.

\section{Permissions}

Construction only is legal when the planning permit are issued. It is an instrument of the government to control the building plans that it fits in the environment and that it is safe and healthy for the users. The Building Regulations are summing up the conditions to achieve the requirements for such a planning permission. The regulations regard constructing, remodelling, demolition and usage of housing. In the case study permissions were needed for construction, demolition and usage of the house. The procedure to acquire the permissions took longer than expected, as result that the construction started almost a year later than planned.

\section{Availability materials \& hiring contractors}

The materialization of the house is an important factor in building cradle to cradle. The environment did not provide building material, only possibilities like water, wind and the soil for climate regulation of the house. To make sure that the materials were cradle to cradle the following procedure was followed: At first a list is made of 
the materials scheduled for the construction. Then the materials were tested on the $\mathrm{C} 2 \mathrm{C}$ principles and the results were used as a basis for the next step. If the material satisfied the principles, it could be used; otherwise the producer was consulted if it is possible to produce the material $\mathrm{C} 2 \mathrm{C}$. This means that the production process and the material itself both needed to be in line with the $\mathrm{C} 2 \mathrm{C}$ principles; the principles were included in the specifications. During this procedure the materialization of the house slowly got visible (Post, 2011). The discussions with the producers lead to inspiration to adapt their production process, but development of a process takes time. As the available time and budget for the construction 'Recht op Wind' was limited, compensation on the materials sometimes was required. Furthermore at that moment the supply of $\mathrm{C} 2 \mathrm{C}$ material was limited, which made it impossible to build $100 \% \mathrm{C} 2 \mathrm{C}$. The following concessions were made, resulting in a substantial adjustment of the design:

1. Instead of a steel skeleton, the walls on the ground floor are made of stones.

2. The roof system changed from case elements into rafters, which is constructed on site. There was no information about the glue used in the construction of case elements, reason why this system became useless for $\mathrm{C} 2 \mathrm{C}$ building.

3. The use of Styrofoam as mould in the foundation

The construction of a $\mathrm{C} 2 \mathrm{C}$ house requires more coordination between producer and contractor than normal. Involving these parties (and all other involved parties) early in the process is essential to accomplish the goal with success. Their motivation and degree of involvement will have a great influence on the final result. During the design process of 'Recht op Wind' agreements about materialization and the producers were made in order to accomplish the intended design, reason why the principal should keep control of the execution phase. Therefore the procurement was divided between several small contractors. Furthermore the construction of the house itself and of the installation was carried out separately (Post, 2011).

\section{Materialization}

The research and design resulted in a house where in no toxics were used and with its own energy system. Furthermore, most part of the construction was a combination of prefab elements, which decreased the waste on site. Another advantage is that construction at the factory guarantees more quality.

The choice of materials is partly based on the environment, which is one of the aspects for designing and building $\mathrm{C} 2 \mathrm{C}$. The finishing parts of the design 'Recht op Wind' are made from wood, zinc, glass and stone which refers to the history of the environment (Post, 2011).

The structural elements of the building are a combination of a steel skeleton and pile construction: the open façade on the ground floor and the complete first floor exists of a steel skeleton while the closed facades on the ground floor are made from clay and light concrete blocks, also known as eco blocks. The stability of the house is derived from these closed facades. A part of the finishing of the closed façade exists of Click bricks, a sustainable brick with a $\mathrm{C} 2 \mathrm{C}$ certificate from EPEA. For the partition walls a timber frame construction is enough with $\mathrm{C} 2 \mathrm{C}$ 
plasterboards. See Figure 4 for a few photographs of the construction. The finishing in the sanitary is a $\mathrm{C} 2 \mathrm{C}$ silver certificate ceramic tile.

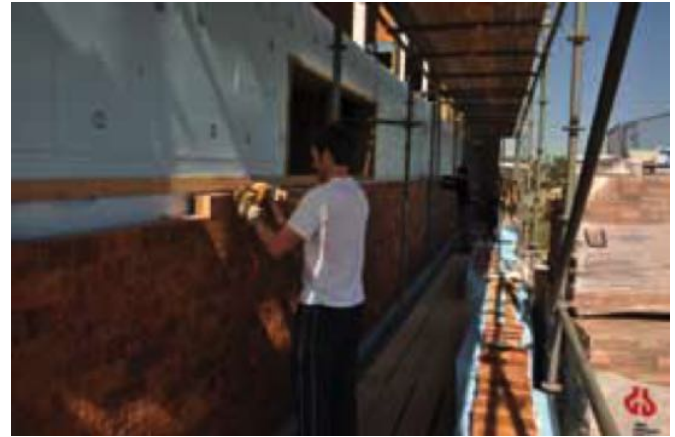

(a)

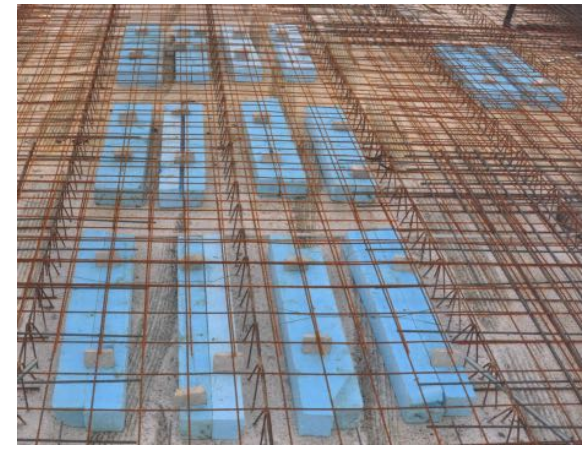

(b)

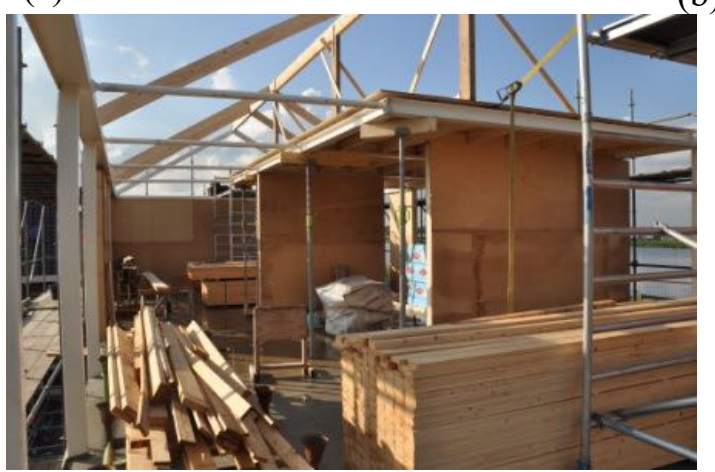

(c)

Figure 4. (a) Construction click bricks ; (b) Styrofoam in floor ; (c) Timberworks Source: Post, 2011; Kolkmeijer, 2012; Timberworks, 2012

The glass in the open façade is AGC triple glass, what is produced by the first $\mathrm{C} 2 \mathrm{C}$ glass producer in Europe (Post, 2011). Their glass is bright, without coating which makes re-use possible (MBDC, 2011). The floors are made of concrete: this is the main cause why the house is not $100 \%$ Cradle to Cradle (Hannema, 2013). At this moment there are no better options, hence the use of concrete. In the design of the floor it is tried to reduce the use of concrete to a minimum by usage of a monolithic floor. This floor is partly filled with the rest parts of the isolation, Styrofoam (see Figure 4). It is possible to re-use the foam after demolishing. As isolation material, Styrofoam plates are used in the walls, floor and roof. The design of the roof is based on this material. The foam is thick, making the roof very height, but from a visual aspect a high roof was not desirable. This problem was solved by not using the isolation foam at the overhang; as a result the roof looks thinner (Post, 2011). The finishing of the roof is made of zinc, which fits well in the environment. A basic detail of the roof can be seen in Figure 5. The roof is made of rafters which require construction on site. 


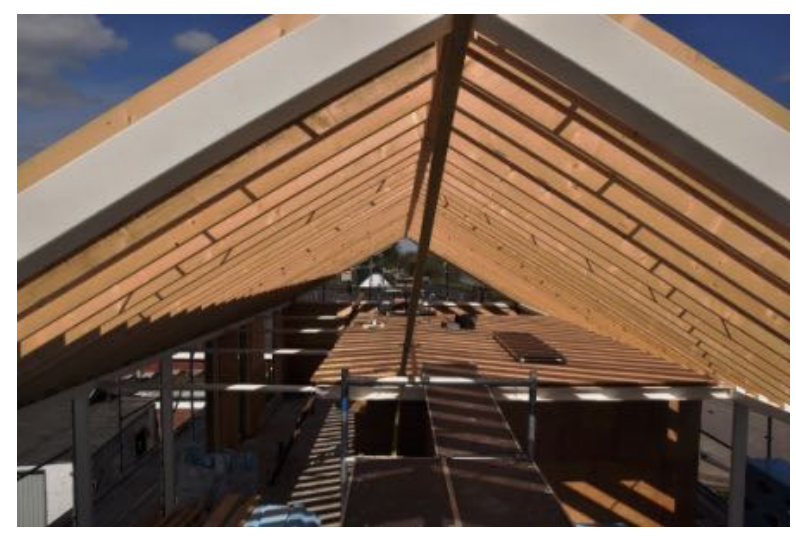

Figure 5. Basic detail roof at entrance side Source: Kolkmeijer, 2012

As already mentioned, the house has an own renewable energy system, with 32 solar panels on the roof, solar collectors and use of the geothermal energy on 125 metres depth with a heat pump. Part of the output of the solar panels delivers the energy needed for the heat pump, while the solar collectors are providing warm water. The solar panels require daily control, so the control panel is placed near the workplace so that it can be checked easily. All the piping is toxic free; the electrical pipes are free of halogen and pvc; water pipes are made of plastics in polypropylene and the sewer is of vitrified clay pipes which is more sustainable than concrete pipes. The home automation, integration of technology and services for better housing and living, is made of certified C2C zinc (Post, 2011).

The ventilation of the house is being regulated without installations, only a ceramic pipe below the house and a fresh air flow through the ventilation grills will do the job (Post, 2011). The extraction is also regulated with natural ventilation. It is not that difficult as it sounds, it is the basic idea of open a window for fresh air, there is enough of it outside.

\section{RESULTS AND DISCUSSION}

\section{Result}

The result is a house that scores $89 \%$ on Cradle to Cradle, which is a good result given the current production conditions. In Figure 7 the score card of the C2Clab design tool can be found, where the building is tested against environment, design, installations and materialisation. 


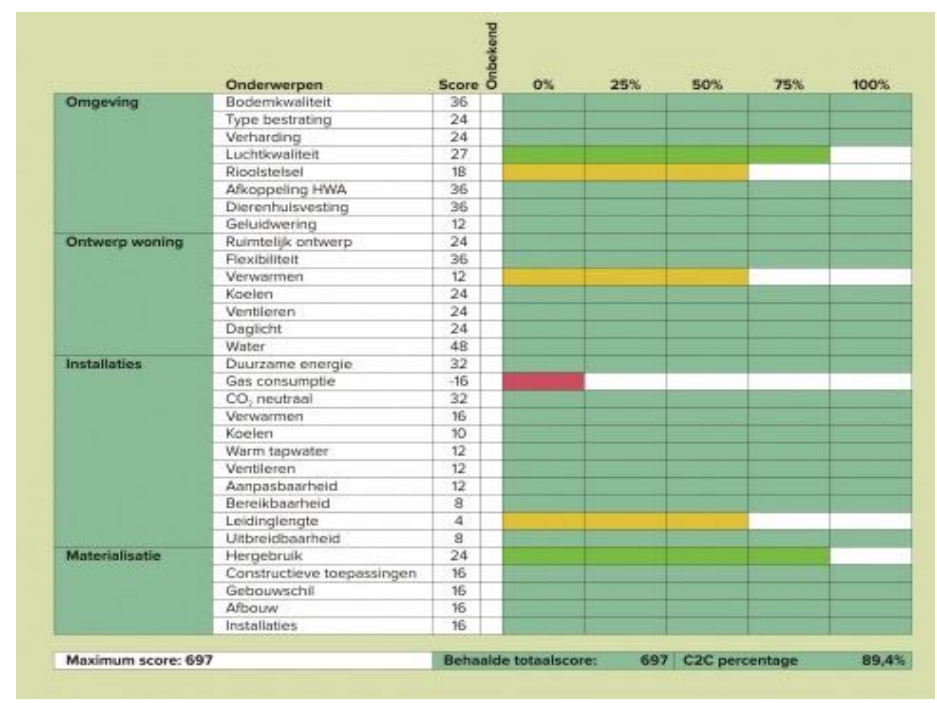

Figure 6. Scoring card C2C lab 'Recht op Wind' Source: C2Clab, 2012

Furthermore, the comfort of the house is good; the rooms are bright and spacious with beautiful views on the environment. See Figure 8 for some impressions of the house. The temperature inside the house constantly is 20 degrees and the air is fresh, of whereby the natural ventilation hardly is noticed. This is the result of a ventilation concept which performs well. Nevertheless the public acceptance of the ventilation concept is still an issue, because of a lack of trust in the system. The house is not self-sufficient yet; at the moment the energy supply is being fine-tuned and the expectation is that the house will be self-sufficient soon. The problem is that there are hardly specific data about the performance of the systems. So the optimal setting of the solar panels and the usage needed to be finetuned based on own experience. For the next project this will be a point for improvement, because when the panels are not completely south oriented they do not catch a maximum of sunlight and there always will be a loss. Another point for improvement is the use of PVC free piping, as the processing of that material was difficult.
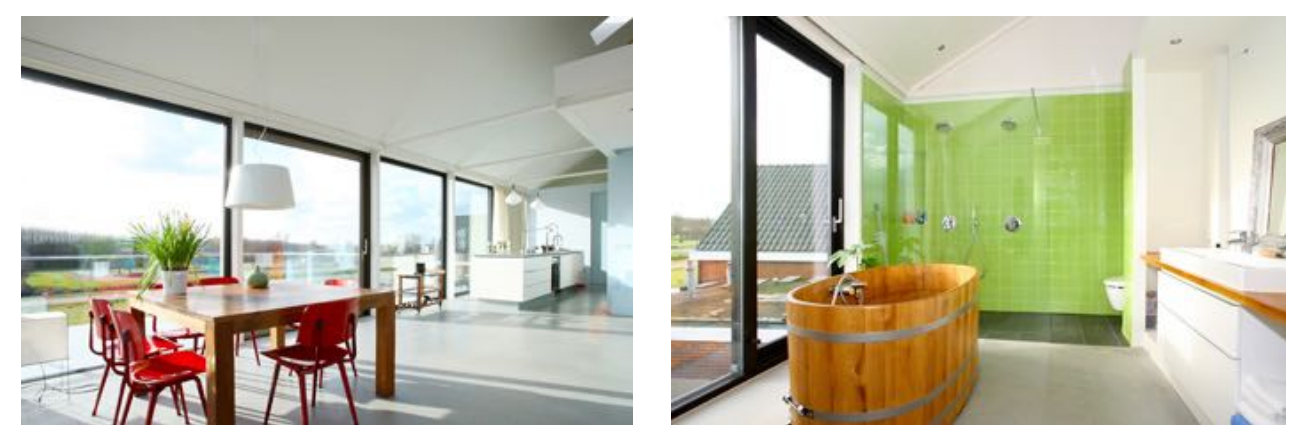

Figure 7. Impressions of result Source: Post, 2012 


\section{Future}

The next project is a complete Cradle to Cradle neighbourhood in Lansingerland, designed with the experience from the construction of Recht op Wind. There is a lot of interest for buying one of these houses. XX architects is responsible for the design, and developed the area with participation of the future residents. Here another type of piping is used; BIO-based, with lactic acid as a raw material. Another improvement will be made regarding the orientation of the solar panels. The expectation is that the $\mathrm{C} 2 \mathrm{C}$ principles will be adapted in the new standards for the building industry (Beemster, 2012), which will make C2C building better accessible and feasible.

\section{Discussion}

Given the definition of Cradle to Cradle in the construction industry the main problem is the availability and supply of materials. Most current materials do not meet the Cradle to Cradle requirements during production process, or regarding the elements of the material itself. It takes much time to find the right materials and systems which are usable for a $\mathrm{C} 2 \mathrm{C}$ building. One option is negotiation with the producer so that the material will fulfil the requirements, which costs a lot of effort from every party. Innovation is necessary, and it is most desirable that more producers change their processes to $\mathrm{C} 2 \mathrm{C}$. But producers, especially in the building industry are conservative: innovation or change costs time and money and bring a lot of risks with them. Subsidy from external parties such as government may help, but in that case the next problem often is that the available budget for such ideas is limited and the current politics are volatile. It is a continuous loop of elements which make change and innovation not attractive. But it will be best if now some producers will change their production processes and materials, because building according the $\mathrm{C} 2 \mathrm{C}$ principles will be a substantial future market. The ones who adjust to those principles will have an advantage or maybe even a monopoly position in the $\mathrm{C} 2 \mathrm{C}$ market.

This is all seen from the given definition of the Cradle to Cradle principles in the building industry: according to these principles it is possible to build a Cradle to Cradle house but it is still a house. Outsiders won't notice the difference between a $\mathrm{C} 2 \mathrm{C}$ house and other houses, what can have a positive as well as a negative effect. People don't like negative changes in their comfort of their living environment, reason why they will keep reservations towards the $\mathrm{C} 2 \mathrm{C}$ principle. In the case study, the public acceptance of natural ventilation is already an issue. This is partly ignorance, but also a longing for safety. If a $\mathrm{C} 2 \mathrm{C}$ building does not deviate from traditional buildings in a negative way, it will be easier to implement $\mathrm{C} 2 \mathrm{C}$ elements in them and public acceptance will be easier. The negative side is that designing over the top and extreme $\mathrm{C} 2 \mathrm{C}$ residential building are difficult to sell, even if the design can result in good and comfortable houses. In the Cradle to Cradle home design contest in the United States, most designs visualised the cradle to cradle aspects very well. The form and materialization were used in an extreme way to show the concept, which creates public awareness of the $\mathrm{C} 2 \mathrm{C}$ principles. It will be 
rather difficult to sell those buildings to private persons, because they usually prefer a more 'normal' home as discussed above.

One important issue is not discussed in full yet: the costs. It is mentioned that some material choices in the case study were partly based on costs, because otherwise it would be too expensive. This problem will exist in every kind of construction project, but because of the limited availability of $\mathrm{C} 2 \mathrm{C}$ materials it will have more influence. Comparing the construction $(300.000 \mathrm{E}$ ex. tax) and installation (55.000E ex. Tax) costs of 'Recht op Wind' with the result building cradle to cradle is possible (Kolkmeijer, 2012). This specific project gives some information about the involving costs, but for an objective view more similar projects are necessary. The next $\mathrm{C} 2 \mathrm{C}$ project in Lansingerland existing of more residential buildings will give more information about the feasibility for constructing affordable $\mathrm{C} 2 \mathrm{C}$ houses. It is a fact that it is necessary to use our resources carefully, because they are being exhausted. Application of the $\mathrm{C} 2 \mathrm{C}$ principles results in the possibility of a continuous life cycle of many resources, in this paper the building materials. Currently it is important that public awareness of the Cradle to Cradle concept is created, because the production process and the decomposition of the products will contribute to a sustainable world. The Cradle to Cradle principles includes both processes whereas sustainability only pays attention to the production process. Building $\mathrm{C} 2 \mathrm{C}$ is the next step after sustainably. It can be considered as a hype, but looking at the last decades sustainability became more and more publicly accepted and major improvements were made such as usage of renewable energy, limited emission of gas and other toxics.

Including $\mathrm{C} 2 \mathrm{C}$ principles in the Building Regulation will lead to a new way of building and designing and ensures that building $\mathrm{C} 2 \mathrm{C}$ will be a new standard. That the total building industry will completely be $100 \%$ cradle to cradle in the future is maybe too ambitious, but the processes and materials in the industry definitely will become more and more cradle to cradle. Therefore, public support and implementation of the principles in regulations are necessary. It will be possible to build a $100 \%$ cradle to cradle house in the near future. Only improvement of the availability of $\mathrm{C} 2 \mathrm{C}$ materials and adjustment of the production processes are needed to reach this aim.

\section{CONCLUSIONS}

The objective of this paper is to investigate the feasibility of designing and building a complete Cradle to Cradle residential building. The example studies and the case study show that it is possible to design a complete Cradle to Cradle house, but that building a complete Cradle to Cradle house is not possible yet. The case study scores $89 \%$ out of $100 \%$ on the $\mathrm{C} 2 \mathrm{C}$ scale, with as most important cause the availability of materials. The systems for inter alia renewable energy are available, but for an optimal use it is important to have more data about the performance of the systems and the production process.

In short; at this moment designing a $100 \%$ cradle to cradle residential building is feasible, building not yet. Building $100 \%$ will be possible when the material 
requirements become standard and when data about the systems become available. The demand exists. There are producers wiling to adjust their products to the $\mathrm{C} 2 \mathrm{C}$ principles. It may be expected that it will be feasible to design and build a complete cradle to cradle residential home in the near future.

\section{ACKNOWLEDGMENT}

I would like to thank Jouke and his wife Petra for telling all kind of stories about the progress of the construction of their new house and the tours. If you are interested in their stories; the website (http://rechtopwind.com/) about the construction of the house tracked by Petra gives a nice view with text and photo's how everything went. Through links, it is possible to access all kind of articles and other media which is published about the house. Reading about building cradle to cradle and how it is applied gives a new insight how it is possible to use materials. It can be a self consciousness but also it can lead to new ideas.

\section{REFERENCES}

Alston, K. (2008) Cradle to Cradle Design Initiatives: Lessons and Opportunities for Prevention throught Design (PtD), Journal of Safety Research, 39, 2.

Beemster, W. (2012) C2C wordt de standaard, Stedebouw \& Architectuur, 2.

Berg, R. v. d., Post, J., Smolders, H., Cromzigt, M., Ramaekers, N., Aussems, T., and Vet, L. (2012). Cradle to Cradle; van 'consuminderen naar consumanderen', Stedebouw \& Architectuur, 6.

C2Clab. (2012) VI resultaten, Retrieved 08-05-2014, 2014, from http://rechtopwind.com/

Cradle 2 Cradle café meetinstrumenten, 18 (2013).

Dobbelsteen, A. v. d. (2008) De Nieuwe Stappenstrategie, Retrieved 18 March 2014, 2014, from http://www.duurzaamgebouwd.nl/onderzoek/20080520de-nieuwe-stappenstrategie

EPEA. (2014a). C2C Materiaal onderzoek. Retrieved 18 March 2014, 2014, from $\mathrm{http} / / \mathrm{www}$.epea.nl/nl/content/c2c-materiaal-onderzoek

EPEA. (2014b). Cradle to Cradle - visie. Retrieved 18 March 2014, 2014, from http://www.epea.nl/nl/content/visie

Hannema, K. (2013, July 2013). Circulair wonen, Architectenweb magazine, 2, 4.

Klooster, J. v. t. (2008) Slimbouwen meets Cradle-to-Cradle, Bouw IQ, 14(3), 4.

Kolkmeijer, M. (2012, 07-01-2013) Recht op Wind. Bouwwereld, 4.

Marshall-Baker, A., \& Tucker, L. M. (2012) Cradle to Cradle home design; process and experience, New York, Fairchild books.

MBDC. (2011) C2C-woning. Stedebouw \& Architectuur, 28(9), 2.

MBDC. (2014) C2C framework. Retrieved 04-06-2014, 2014, from http://www.mbdc.com/cradle-to-cradle/c2c-framework/

News, S. B. (2013) LEED brings Cradle to Cradle into green building certification. Retrieved 
http://www.greenbiz.com/news/2013/07/17/leed-cradle-cradle-certificationgreen-building

Post, J. (2011) De C2C-woning, Stedebouw \& Architectuur, 28(9), 10.

Post, J. (2012) Photo's of Construction period, Bergschenhoek.

Timmermans, T. (2014) Cralde to Cradle. Retrieved 18 March 2014, 2014, from http://www.groeneofferte.n1/kennisbank/cradle-to-cradle

Velden, F. v. (2012) Ingenieurs wijzen organisaties de weg naar cradle to cradle, Cobouw(4), 1. 